\title{
The Impact of China's Aid on Zambia's Economic Growth: An ARDL Technique
}

\author{
Mr. Bravo Muchuu ${ }^{1^{*}} \quad$ Suzyo Kasanga ${ }^{2}$ \\ 1.Lecturer/Researcher, Department of Economics, Copperbelt University P.O. Box 21692, Kitwe, Zambia \\ 2.Student, Copperbelt University, P.O. Box 21692, Kitwe, Zambia
}

\begin{abstract}
Theory suggests that aid holds a more vibrant role to the host nation's economic performance, as it contributes to profitability gains and technological spill-overs. It is from the just highlighted hypothesis that this study opted to outline possible consequences of China's aid on Zambia's economic growth during the 1991 to 2018 period. To draw conclusions over the subject matter, the study resorted to utilising the Autoregressive Distributed Lag Model (ARDL) which connected the explained variable to four explanatory variables. Having held other factors that could influence Zambia's GDP constant, three of the indicators for China's aid exhibited positive effects in the long-run. On the contrary, an indicator for Chinese militia assistance did not pose positive outcomes. Thus, the study concluded by strongly recommending for a reduction in the application of the military financial assistance from China by the Zambian Government because such support diminished the growth of Zambia's GDP during the study period.
\end{abstract}

Keywords: Aid, GDP, Economic growth.

DOI: $10.7176 / \mathrm{JESD} / 10-14-11$

Publication date:July $31^{\text {st }} 2020$

\section{Introduction}

Aid has been a source of that supplementary finance that most emerging nations lack in meeting their budget deficits. Over the recent years, the Zambian government has greatly benefited from the strong bilateral ties that it shares with China ranging from trade as well as financial assistance (Chileshe, 2010). Traditionally, the flow of finance from the Western countries into a local boundary has been perceived to focus mainly on profit-making rather than promoting growth.

It is for this reason that most Chinese ventures in Zambia have been termed as "market explorers", that is, once these companies are functional, they utilize Zambia's pivotal location to trade their produce with the neighbouring nations. A good example is the China Henan International Cooperation GroupCo Ltd, a company renowned for its quality road creation, succeeded capturing of most road construction deals during the early 2000's which later saw it spread to the rest of Central and Southern Africa (Khan, 2015).

Furthermore, the presence of Chinese investors in Zambia has been coupled with a great desire for lasting money-making ambitions as this was evident from their purchasing of Zambia's Luanshya and Chambishi mines on the Copperbelt Province. Finally, a summary of investment inflows from abroad as a share Zambia's economic growth can be highlighted in the figure below.

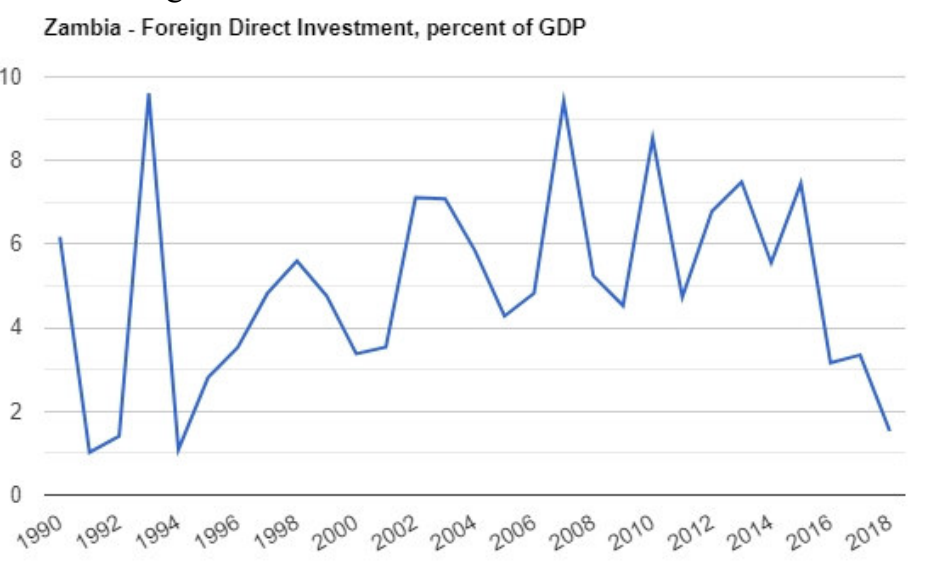

Source: TheGlobalEconomy.com, The World Bank

Figure 1.0 Zambia-Foreign Direct Investment

The up and down trends as depicted in figure above was as a result of both internal and external shocks which posed a major influence on FDI attained and thus influencing GDP. 
Surprisingly, China has come to the rescue of Zambia's deficiencies on several occasions. One famous instance alludes to the construction of the Tanzania Zambia Railway line in the 1970's, this was after the Zambian and Tanzanian governments had moved across the globe in search for assistance and it was China that came to the rescue (Dudhia, 2020). Today, the TAZARA railway line is supporting in the transportation of heavy cargos as well as providing revenue for both nations.

Additional support towards infrastructure improvements was observed in the financing of a \$10million worth of a grant to the Zambian government towards the completion of the stadium in the city called Ndola, not to leave out the building of the Zambia Statistical Agency (formerly known as Central Statistical Office and the National Malaria Centre which were also funded by the Chinese aid (Tierney, 2017). With these and many more support openings from the China, the figure below shows a summary of trends concerning aid that been flowing in to support Zambia's military service and to pardon on some of debts from the year 1990 to 2018 and so on.

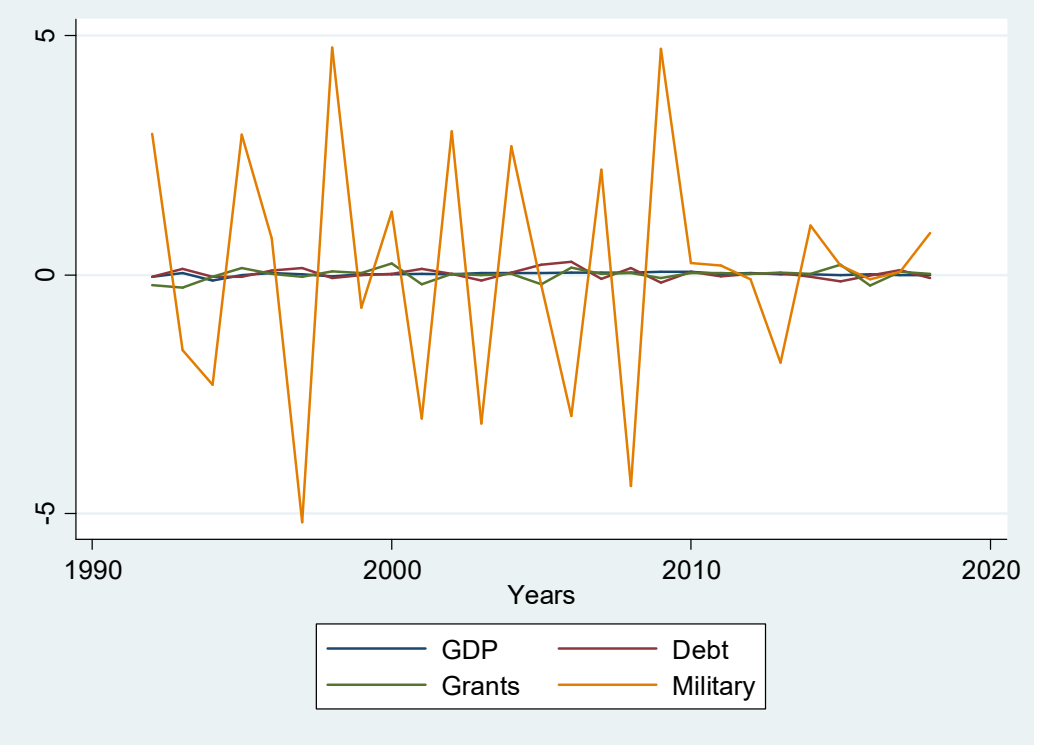

Figure 1.1 Trends of GDP and Aid

(Source Aid Data, https://www.aiddata.org/)

According to the figure 1.1 above, with a downward trend in the grants, debt written off and military aid from China, will correspond to a downward trend in Zambia's GDP.

Therefore, aid has generally been believed to improve economic growth though its impact has been under appreciated as much emphasis is dwelled on other means growth. Knowing that most of the Zambia's assistance comes from China, it is therefore imperative to investigate the impact of the Chinese aid on Zambia's economic growth. Solving the aid puzzle, this study will not only prepare governments and policy makers but also inform the readers of the know-about.

\section{Theoretical Literature Review}

Africa's connection with China is a basically a relationship where the two parties are subject to one another. However, the extent of this connection cannot be compared, for instance, Africa would be in need of developmental assistance whilst China would want to source for a market for its produce, nevertheless, the two players are reliant on one another (Morris, 2013). Additionally, the China-Africa affiliation has a direct consequence on both parties, for example, Africa has the natural resources and the market required by China, and on the other hand, China has the financial assets that Africa needs. Enuka (2011) made the same observation as he labelled both Africa and China to be interdependent on each other.

A theory that would model this kind of a relationship can be identified as the interdependence theory. A broad and complex theory that was postulated during the 1970's, has changed over time but its basic principles have remained the same. Interdependence is generally defined as mutual dependence between two entities. All depending on the theme, some scholars such as Benson et al., (2007) and Masterson (2009) for instance have associated the concept of Interdependence with peacemaking or conflict escalation during the process of trade.

While Keohane et al., (1977) on the other hand, depicted Interdependence as a situation whereby, states or actors are determined by external events in a reciprocal relationship with other states or actors, jointly limiting their autonomy. Created through the expansion of international transactions, with the benefits exceeding the cost, this description of Interdependence by Robert Keohane and Joseph Nye greatly captures the current nature and scope of the China - Africa relation in accordance with the arguments postulated by friends of this relationship. 


\section{Empirical Literature Review}

Several studies have been conducted from many parts of the world regarding the theme of aid. Among some of them involves a research by McGillivray (2005), which focused on the impact of aid on selected African countries. While conducting the analysis, little did he realize that aid not only help to African nations grow economically but as well diminishes levels of poverty. The study was settled in a manner that recommended for host countries to adopt favorable policies that concern trade openness and inflation, because he believed that they influence the amount of aid obtained.

Ram (2004), also took a step to understand possible stimulants of foreign aid drawn from the foreign country. In his study, foreign aid was noted to be directly to the policies of the recipient countries which will further impact its economic development and poverty levels. Thus, the author concludes that sending aid to countries with better policies contributes to higher levels of economic growth and poverty reduction.

(addison, et al., 2005) examined drifts in aid to Africa from 1960 through 2002. The writers mainly highlight the huge decrease in aid received a decade ago that will influence the living standards as well as the entire African economy which will see most African countries failing to meet the MDGs because of deficit in funding. This paper argues that aid is currently improving development and reducing poverty.

(Ouattara., 2006) analyzes the influence of aid flows on key Senegalese fiscal aggregates. This paper uses data from 1970-2000 and focuses mainly on the relationship between aid and debt. The author has listed three of his study's key findings. First, a substantial portion of aid flows are used to fund Senegal's debt, about 41 percent, and 20 percent of government resources are allocated to debt servicing. Second, the effect on domestic spending of aid flows is statistically negligible, and third, debt servicing has a substantial negative effect on domestic spending. In his research he utilized non-linear three-stage least square (N3SLS) technique.

A research carried out by Karras (2006), examines the correlation between foreign aid and per capita GDP growth using annual data from 1960 to 1997 for a sample of 71 developing countries receiving aid. This paper concludes that the impact on economic growth by foreign aid is optimistic, lasting and statistically important. More precisely, the study found that a permanent increase of $\$ 20$ per citizen in foreign aid results in a permanent increase of 0.16 per cent in the growth rate of real GDP per capita. Such findings are obtained without taking into account the effects of policy.

Snyder (1993) modified the regression model of Mosley (1980), by taking into consideration country size in his regression. Where, country size was measured by Gross Domestic Product. He found that when country size variable is incorporated into regression, a positive and significant relationship between aid and growth can be shown to exist. The author believed that contradiction between micro and macro impacts of aid on growth can be further explained by adding the variable of country size into regressions, which was ignored by earlier literature.

Griffin and Enos (1970) found the negative relationship between economic growth and foreign aid, despite admitting the limitation to the availability of data. They criticized the typical growth model assumptions that investment increases by the same amount of foreign inflows which leads to higher rate of capital accumulation. Moreover, the assumption that recipient country is unwilling or unable to increase aid merely to increase consumption and have no incentive to increase aid by reducing savings was also criticized. They argued that foreign inflows supplant rather supplement domestic savings. Moreover, aid does give incentive to government and private entrepreneurs not to restrict their own consumption and government will also refrain from raising taxes. In other words, aid frequently becomes a substitute for tax reforms and as long as the cost of foreign inflows is lower than the incremental capital output ratio (IOCR), country has incentive to continuously borrow, thus reducing domestic savings.

\section{Research Method}

\subsection{Description of Variables and Data Source}

With assistance from the aiddata website and other relevant literature, this study was successful in coming up with a dataset to trace possible links between Chinese aid and Zambia's GDP growth, whereas the World Bank website provided data on GDP. Further, all variables collected on Chinese aid are in millions of dollars, to do the analysis easier, they were rounded off to the nearest ten thousand $(10,000)$, a natural logarithm was then utilized on the variables to reduce on the variations and make them well behaved. A brief description of the variables can therefore be given as;

1. GDP Annual Growth; defined as a growth in a nation's output in a year. It is calculated for in US dollars at 2005 prices. A much more previous value of GDP was utilized to acknowledge the contribution of Chinese impact on GDP growth.

2. Chinese aid towards the completion of Zambia's developmental projects; it is measured in millions of dollars

3. Chinese military aid; Military aid activities that are earmarked for non-developmental to Zambia measured in millions of US.

4. Debt forgiveness; Amount of China's loans to Zambia that are written off at Constant US dollar prices 
5. Chinese grants to Zambia; a monetary measure of China's grants to Zambia in millions of US dollars at constant prices.

\subsection{Model Specification}

The connection between Chinese and Zambia's GDP can be modelled by the equation below;

$$
G D P=\beta O+\beta 1 D E V E+\beta 2 M I L I T A+\beta 3 D E B T+\beta 4 G R A N T+\varepsilon i \ldots \ldots \ldots \ldots \ldots 1
$$

Where GDP is GDP is the annual growth in Zambia's GDP

DEVE is the financial assistance towards developmental projects

MILTA is Chinese aid to the military service in Zambia

DEBT is the amounts of loans written off

GRANT is nominal measure of Chinese grant to Zambia between 1991 and 2018

\subsection{Estimation Procedure}

Having modelled the relationship between FDI and GDP growth, this piece of writing wishes to adopt the autoregressive distributed lag (ARDL) model, the basis of this model selection is because of its capabilities to accommodate differentiated orders of integration. After conducting the cointegration tests, the ARDL model was also employed to estimate the long-run dynamics with aid from the Error Correction Model (ECM). Whereas the ordinary ARDL will estimate the short-run position of the model. An estimation short-run and long-run relationship between Chinese aid and Zambia's economic growth can be modelled by the equation below;

$$
\begin{aligned}
& \Delta I n G D P_{t}=\alpha_{0}+\sum \alpha_{11} \Delta I n D E V E_{\mathrm{t}-1}+\sum \alpha_{21} \Delta \operatorname{InMILITA}_{\mathrm{t}-1}+\sum \alpha_{31} \Delta \operatorname{InDEBT} T_{\mathrm{t}-1}+\sum \alpha_{41} \Delta \operatorname{InGRANT} T_{\mathrm{t}-1} \\
& +\lambda E C T_{\mathrm{t}-1}+\mu_{\mathrm{t} .}
\end{aligned}
$$

Where;

i. $\lambda E C T_{t-1}=$ is the error correction term used to estimate the long-run relationship of the Variables

ii. and the rest of the equation above is used to estimate the short-run effects

\subsection{Unit Root Tests}

In testing for stationarity, unit root tests are employed, times series data with zero mean, constant variance, and is serially uncorrelated is said to be stationary. Why worry so much about stationarity one would ask; Green (2012) tells that a stochastic process that is non-stationary will result in one running a nonsensical kind of regression. Additionally, we care so much about stationarity because a non-stationary stochastic process will have less policy implication and has little value in forecasting purposes (Wooldridge, 2009). The unit root model is given by;

$Y t=\rho Y t-1+\mu t-1 \leq \rho \leq 1$

According to the above heighted equation, when $\boldsymbol{\rho}$ is equal to one, it is known as a random walk without a drift, meaning that this stochastic process is non-stationary. Whereas, if $|\boldsymbol{\rho}|<1$, the model Yt has no unit root so it's a stationary.

There are several models employed in the unit root test, but the center of focus for this study will be grounded on the Augmented Dickey-Fuller test which takes the following form.

$$
\Delta \boldsymbol{Y}_{t}=\boldsymbol{\beta}_{1}+\boldsymbol{\beta}_{2} \boldsymbol{t}+\boldsymbol{\delta} \boldsymbol{Y}_{t-1}+\Sigma \boldsymbol{\alpha}_{i} \Delta \boldsymbol{Y}_{t-1}+\varepsilon_{t}
$$

The hypothesis is given as

$\mathrm{H}_{0}: \delta=0$ ( $\mathrm{Y}_{\mathrm{t}}$ has a unit root/ non-stationary)

$\mathrm{H}_{1}: \delta \neq 0$ ( $\mathrm{Y}_{\mathrm{t}}$ is stationary).

$\mathrm{Y}_{\mathrm{t}}-$ dependent variable under consideration

$\mathrm{t}$ - time trend

$\varepsilon_{\mathrm{t}}-$ pure white noise term

4.4.1 Philips-Perron

The Philips-Perron test of stationarity will utilized to compliment the Augmented Dicky Fuller (ADF) test of stationarity with null hypothesis being that that the variables are non-stationary against the alternative that the variables are of stationary in nature. The PP test of stationarity accounts for the issues of autocorrelation and heteroscedasticity in a manner that the ADF would not (Green, 2012).

\subsection{Cointegration}

Gujarati (2009) defines that two variables are cointegrated in the event that they have a long run or equilibrium connection between them. Cointegration becomes a crucial requirement in any economic model because if variables do not cointegrate, then we will face problems of running a spurious regression making our econometric work meaningless. It is for this reason that this study uses the Autoregressive Distributed Lag Bounds test for cointegration.

\section{Data Analysis}

Microsoft excel and a statistical software called STATA 13 were used for data analysis. 


\subsection{Introduction}

This section presents outcomes of the data analysis. It comprises of the readings of the results in terms of the direction of the relationship between the dependent and independent variables and the statistical significance of coefficients.

\subsection{Descriptive Statistics}

A brief summary of the mean, standard deviation, number of observations, minimum and maximum values for the variables under consideration will be highlighted in the descriptive statistics. This can be presented in the table below;

Table 5.0 Descriptive Statistics

\begin{tabular}{|l|c|l|l|l|l|}
\hline Variable & Observations & Mean & Standard Observations & Minimum & Maximum \\
\hline InGDP & 28 & 7.084807 & 0.2343695 & 6.809678 & 7.413862 \\
\hline InDEVE & 28 & 4.328472 & 1.380939 & 1.808289 & 6.495265 \\
\hline InMILITA & 28 & 4.309462 & 1.55743 & .1823216 & 5.991465 \\
\hline InDEBT & 28 & 4.289813 & 0.2889129 & 3.829034 & 4.702902 \\
\hline InGRANT & 28 & 2.915988 & 0.1474261 & 2.607376 & 3.249313 \\
\hline
\end{tabular}

According to the to the table above InGDP has a mean of 7.084807 and a very low standard deviation of 0.2343695 , indicating that it was relatively stable. Further a minimum value of 6.809678 and a maximum value of 7.413862 , implying that there are a few variations in the sample during the study period. The same could be said about the other variables.

\subsection{Correlation Matrix}

The study took a step further to understand how the variables relate, this was assisted by the correlation matrix test which can be presented in the table below;

Table 5.1 Correlation Matrix

\begin{tabular}{|l|c|l|l|l|l|}
\hline Variable & InGDP & InDEVE & InMILITA & InDEBT & InGRANT \\
\hline InGDP & 1.0000 & & & & \\
\hline InDEVE & 0.2683 & 1.0000 & & & \\
\hline InMILITA & 0.0961 & 0.1673 & 1.0000 & & \\
\hline InDEBT & 0.8497 & 0.3288 & 0.0942 & 1.0000 & \\
\hline InGRANT & 0.6487 & 0.0612 & 0.1797 & 0.4635 & 1.0000 \\
\hline
\end{tabular}

The results in table 5.1 above imply that InDEVE has a positive and a low correlation of 0.2683 with InGDP. Further, InMILITA has positive and a much lower correlation with InGDP than InDEVE of 0.0961. Likewise, InDebt has a positive and a higher correlation with InGDP of 0.8497 but has a very low correlation with in InMILITA of 0.0942. InGRANT, as well displays positive and high correlations with InDEBT and InGDP respectively but that is not the case with InDEVE and InMILITA which InGRANT correlates with in a lowly manner.

\subsection{Stationarity Test}

The study appealed to the two to the two prominent tests for stationarity, which is the Augmented Dicky-Fuller (ADF) and the Philips-Peron. The results can be summarized in the table below;

Table 5.2 Stationarity Test

\begin{tabular}{|l|l|l|l|}
\hline Variable & Order of Integration & $\begin{array}{l}\text { Augmented-Dicky-Fuller } \\
\text { (P-value) }\end{array}$ & $\begin{array}{c}\text { Philips-Peron } \\
\text { (P-value) }\end{array}$ \\
\hline InGDP & Level & 0.4972 & 0.9778 \\
\hline InDEVE & Level & $0.0016^{*}$ & $0.0011^{*}$ \\
\hline InMILITA & Level & $0.0020^{*}$ & $0.0000^{*}$ \\
\hline InDEBT & Level & 0.8347 & 0.6074 \\
\hline InGRANT & Level & $0.0008^{*}$ & 0.1189 \\
\hline
\end{tabular}

NOTE: *,** Implies significance at the $1 \%$ and $5 \%$ level respectively

Going by the results in the table above, InDEVE and InMILITA are stationary at level from both the Augmented-Dicky Fuller (ADF) and Philips-Peron test (PP), the basis of this choice selection was after we peacefully failed to reject the null hypothesis that the variable in use does exhibit constant mean and variances over time at a $1 \%$ level of significance. To make conclusions regarding the stationarity of InGDP, InDEBT and InGRANT, these variables had to be differenced. The table below demonstrates stationarity results after the first difference; 
Table 5.3 Stationarity Test

\begin{tabular}{|l|l|l|l|}
\hline Variable & Order of Integration & $\begin{array}{l}\text { Augmented-Dicky Fuller } \\
\text { P-value }\end{array}$ & $\begin{array}{c}\text { Philips-Peron } \\
\text { P-value }\end{array}$ \\
\hline InGDP & First & $0.0322^{* *}$ & $0.0004^{*}$ \\
\hline InDEVE & Level & $0.0016^{*}$ & $0.0011^{*}$ \\
\hline InMILITA & Level & $0.0020^{*}$ & $0.0000^{*}$ \\
\hline InDEBT & First & $0.0004^{*}$ & $0.0000^{*}$ \\
\hline InGRANT & First & $0.0000^{*}$ & $0.0000^{*}$ \\
\hline
\end{tabular}

NOTE: *,** Implies significance at the $1 \%$ and $5 \%$ level respectively

InGDP, InDEBT and InGRANT only became stationary after the first difference as indicated in the table above. It can therefore be concluded that InDEVE and InMILITA are integrated of order zero and InGDP, InDEBT and InGRANT are integrated of order one. It is for this reason that this study will appeal to the Autoregressive Distributed Lag Model (ARDL) based on differentiated orders of integration.

\subsection{Lag Selection Criteria}

Table 5.4 Optimal Lag Selection

\begin{tabular}{|l|l|l|l|l|l|l|}
\hline Lag & LL & LR & FPE & AIC & HQIC & SBIC \\
\hline $\mathbf{0}$ & -41.1695 & & .000032 & 3.84746 & 3.91257 & 4.09289 \\
\hline $\mathbf{1}$ & 46.0618 & 174.46 & $1.9 \mathrm{e}-07$ & -1.33848 & -.947809 & $.134085^{*}$ \\
\hline $\mathbf{2}$ & 72.7041 & 53.285 & $2.3 \mathrm{e}-07$ & -1.47534 & -.75911 & 1.22436 \\
\hline $\mathbf{3}$ & 107.942 & $70.476^{*}$ & $2.7 \mathrm{e}-07$ & $-2.32853^{(*)}$ & $-1.28673^{*}$ & 1.59832 \\
\hline $\mathbf{4}$ & & & $-1.5 \mathrm{e}-38^{*}$ & & & \\
\hline
\end{tabular}

Note: $(*)$ Indicates the number of lags that the model will assume as displayed by the Akaike Information Criterion (AIC).

To decide the maximum number lags to be used in the model, with aid from the Varsoc STATA command, three (3) lags selected. The decision rule for the optimal lag selection is that you pick the value which corresponds to the lag value on the information criterion (AIC, HQIC and SBIC) that has the lowest value, in this case it was the Akaike Information Criterion (AIC) this is displayed in table 5.4 above.

\subsection{Cointegration Test}

Cointegration tests used to test if variables exert a long-run relationship over time. Of the many tests that can be applied to test for cointegration, this study will engage the bounds test for cointegration due to its great competence and efficiency in dealing with small samples. Therefore, the bounds test will be responding to the null hypothesis stated below as;

Ho: No levels relationship

$H_{1}$ : There exists a relationship in the long-run

Whilst facing the decision rule, accept Ho if $\mathrm{F}<$ critical value for I $(0)$ regressors

\begin{tabular}{|c|c|}
\hline Lower Limit I(0) & Upper Limit I(1) \\
\hline 2.45 & 3.52 \\
\hline 2.86 & 4.01 \\
\hline 3.25 & 4.49 \\
\hline 3.74 & 5.06 \\
\hline
\end{tabular}

Following the bounds tests outcomes in STATA as indicated in the table above, the null hypothesis was, rejected in the null in favor of the alternative if F-statistic is above I (0). As the results clearly indicate, we can safely reject the null hypothesis and settle for the alternative. 


\subsection{Long-run and Short-run ARDL Dynamics}

Table 5.6 Long-run (LR) and Short-Run Dynamics from the ARDL Regression

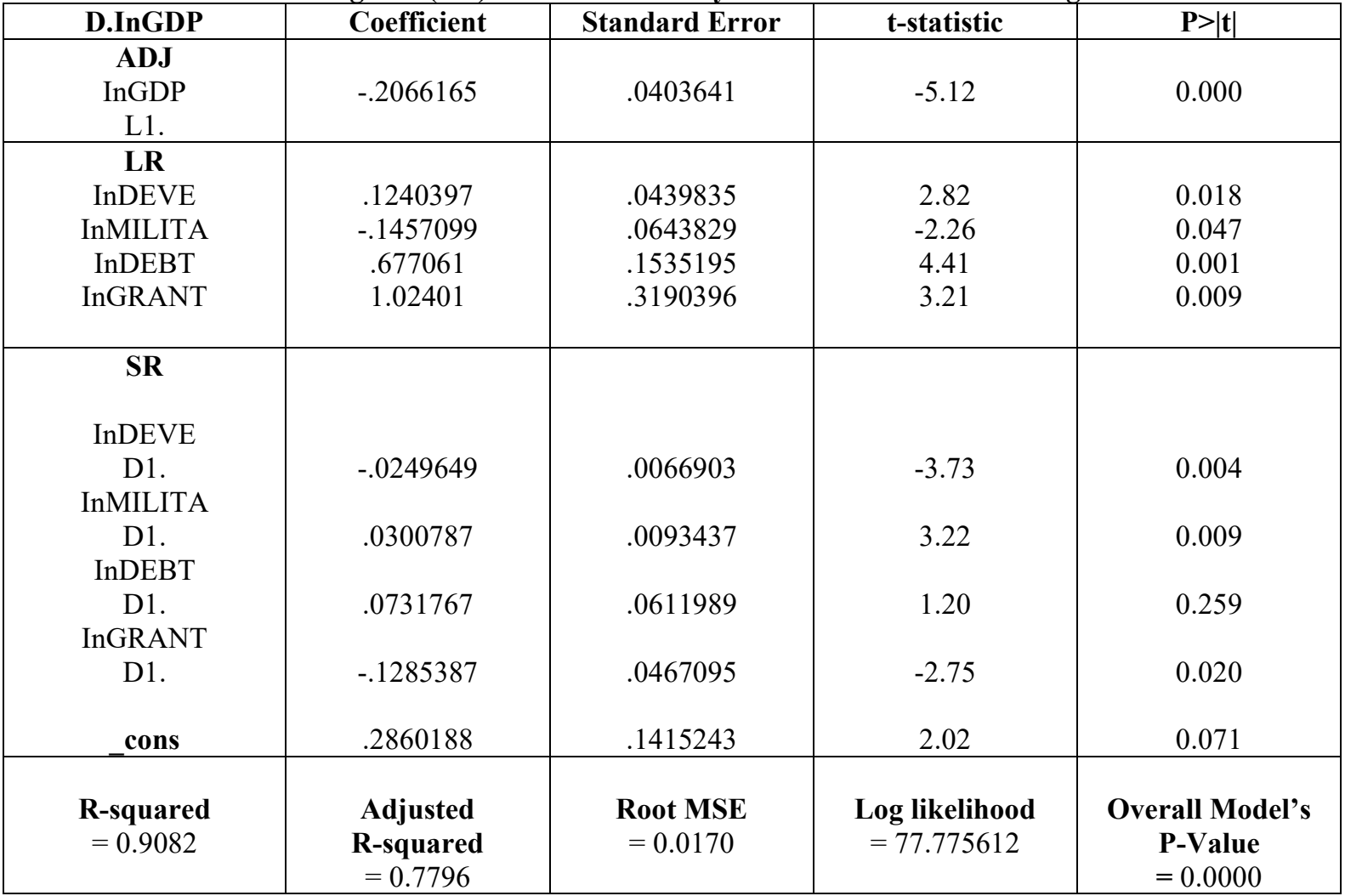

Having estimated the above model it was noted that adjustment term (ADJ) was observed to be negative, entailing that causality is flowing from the independent variables to the dependent variable. The negative figure of -.2066165 on the adjustment term indicates that the variables will converge to restore equilibrium in the longrun at a speed of $20.66 \%$. With an $R^{2}$ of 77.96 (adjusted R-squared) of the variations in InGDP being explained by the independent variables, leaving $22.04 \%$ of the variations unexplained.

In the long-run a percentage point increase of Chinese aid towards the completion of developmental projects (InDEVE) in Zambia, will on average result in the expansion of Zambia's GDP by 0.1240397 , other things constant. An additional percentage point increase of Chinese aid towards Zambia's military service or military activities will diminish the growth of Zambia's GDP by 0.1457099 ceteris paribus.

Should China opt to forgive Zambia on some of its outstanding debts (InDEBT) by a percentage point, will in the long-run result in the growth of Zambia's GDP by 0.677061 on average this after holding other factors that can affect GDP constant. Further, with a one percentage point increase of Chinese grants (InGRANT) to Zambia, will on average increase Zambia's GDP by 1.02401, ceteris paribus.

In the short-run, statistically significant and positive outcomes on Zambia's GDP will result after a percentage point increase of Chinese aid at first difference (D1), ceteris paribus.

\subsection{Diagnostics Tests}

In order to make policy recommendations based on the ARDL outcomes, diagnostic tests had to be conducted and the results can be summarized below;

Table 5.7 Diagnostic Test Results

\begin{tabular}{|l|l|l|c|}
\hline Diagnostic Test & \multicolumn{1}{|c|}{ Test } & Test-statistic & P-value \\
\hline \multirow{2}{*}{ Autocorrelation } & Breusch-Godfrey & & 0.2582 \\
\cline { 2 - 4 } & Durbin-Watson & (d-statistic) $=2.208343$ & \\
\hline Heteroscedasticity & White test & & 0.4390 \\
\hline Missing Variables & Ramsey Reset & & 0.5728 \\
\hline Normality & sktest resid & Mean VIF $=1.15$ & 0.7634 \\
\hline Multicollinearity & Variance Inflating Factor & & \\
\hline
\end{tabular}

Autocorrelation is absent as this is confirmed by the d-statistic of 2.208343 which above the R-squared of 0.9082 , this is resolved further by the p-value of the Breusch-pagan of 0.2582 which is above the three levels of significance that is at $1 \%, 5 \%$ and $10 \%$. Hence, we reject the null hypothesis that our variables are related over 
time.

According to the Ramsey reset test for missing variables, we could not reject the null hypothesis in favor of the alternative that the model has no missing variables as the p-value of 0.5728 is in excess of the three levels of significance.

The skewness tests for normality, suggest that the residuals are normally distributed, this was confirmed after it was noted that the p-value of 0.7634 is in excess of the three levels of significance and this is sketched in the figure below.

And lastly, the variance inflating factor (VIF) of 1.15 indicates that our model is not suffering from multicollinearity, this confirmed by the fact that our VIF value is not in excess of 10 .

Table 5.8 Normality Plot

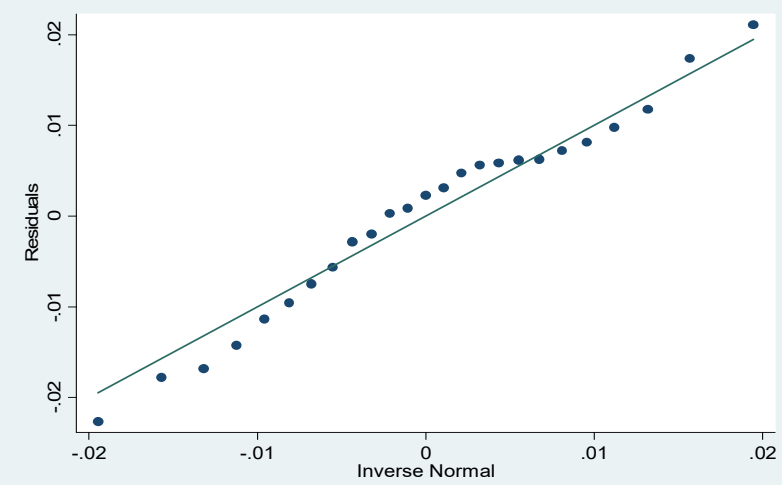

The residuals for the model were normally distributed as shown by the normality plot above.

\subsection{Model stability}

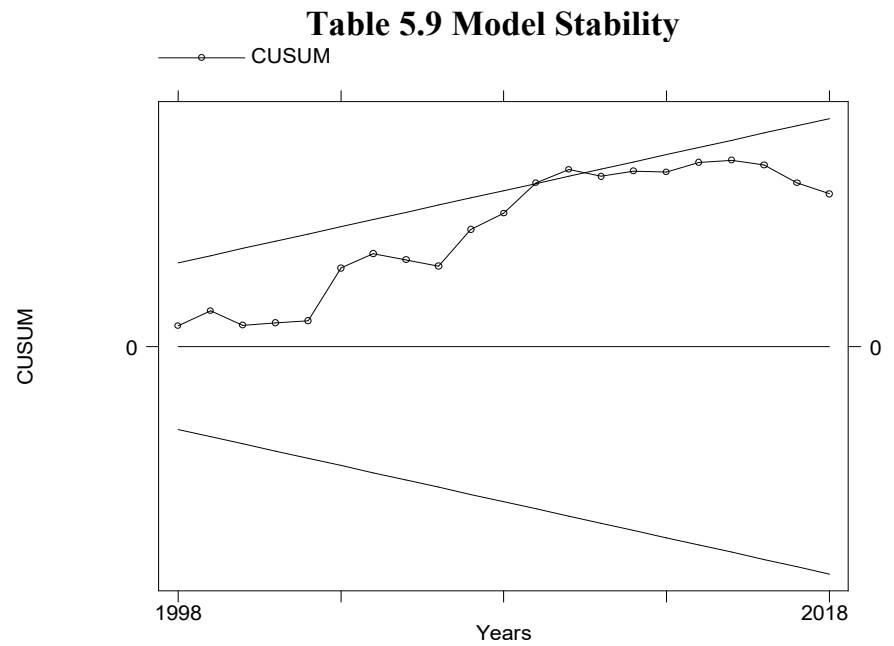

The model is relatively stable as it lies in between the two boundary lines.

\section{Conclusion}

The aim of this study was to explore the impact of the Chinese Aid on Zambia's economic growth. It was revealed that in the long-run, a percentage point increase of Chinese Aid towards the completion of developmental projects in Zambia will on average result in the expansion of Zambia's GDP by 0.1240397 , other things constant. An additional percentage point increase of Chinese Aid towards Zambia's military service or military activities will diminish the growth of Zambia's GDP by 0.1457099 ceteris paribus. Should China opt to forgive Zambia on some of its outstanding debts (InDEBT) by a percentage point, will in the long-run result in the growth of Zambia's GDP by 0.677061 on average this after holding other factors that can affect GDP constant. Further, with a one percentage point increase of Chinese grants (InGRANT) to Zambia will on average increase Zambia's GDP by 1.02401, ceteris paribus. With 77.96 (adjusted R-squared) of the variations in InGDP being explained by the independent variables, leaving $22.04 \%$ of the variations unexplained is a very reliable analysis. In the short-run, statistically significant and positive outcomes on Zambia's GDP will result after a percentage point increase of Chinese aid at first difference (D1), ceteris paribus. 


\section{Recommendations}

In many ways, the China - Zambian relationship has vacillated through both high and low points - the continuous use of Chinese workers, the unbalanced nature of burgeon trade ties continues to loom the psyche of Zambians who sometimes think Chinese Aid to Zambia is a diplomatic debt trap. However, the findings suggest that the Chinese Aid towards Zambia's military service or military activities diminishes the growth of Zambia's GDP. Thus, the Zambian Government should not opt for any militia assistance from China. It will however, be wise for the Zambian Government to humbly request for more debt cancellations especially amidst the Covid 19 pandemic. This will help boost economic growth by about $68 \%$. Lastly but not the least, the Zambian Government should continue keeping a cordial relationship with China for more grants that will boost economic growth. It will also be very important for the Zambian Government to be able to use the grants from China productively in order for them to pay back the huge debt owed to China.

\section{References}

Addison , 2005. Aid to Africa; An Unfinished Agenda. Journal of International Development, Volume 17, pp. 989-1001

AidData, 2020. AidData. [Online] Available at: https://www.aiddata.org[Accessed 25 May 2020].

Chileshe, 2010. Chinese Debt, Aid and Trade:Opportunity or Threat for Zambia?, s.1.: s.n.

Dudhia, 2020. Musa Dudhia and Co. [Online] Available at: https://www.africalegalnetwork.com/zambia/news/silk-road-or-dragon-path-the-impact-of-chineseinvestment-in-zambia/[Accessed 25 May 2020].

Enuka, 2011. Aid in Sino-African Relation:An analysis of Promting and Problems of China's. The IUP Journal of International Relation, Volume 2, pp. 41-53.

Greene, 2012. Econometric Analysis. 5th ed. s.1.:s.n.

Griffin and Enos, 1970. Foreign Assistance: Objective and Consequences. Economic Development and Cultural Change, pp. 313-327.

Gujarati, 2009. Basic Econometrics. 5th ed. s.1.:s.n.

Karras, 2006. Foreign Aid and Long Run Economic Growth: empirical evidence for a panel of developing countries. journal of internation develoment, Volume 7, pp. 15-28.

Khan, 2015. China-Africa Economic Relation, s.1.: s.n.

McGillivray, 2005. Is Aid Effective, s.l.: s.n.

Morris, 2013. Implications of Deepening Relationship. [Online] Available at: https://www.rand.org/pubs/research_briefs/RB9760.html [Accessed 25 May 2020].

Ouattara, 2006. Governments Fiscal Behaviour in Developing Countries and Foreign Aid: Panel Data Evidence. Economic Modelling, Volume 23, pp. 506-514.

Ram , 2004. Effects of Aid on Economic Growth and Policies of Reciepient Countries. Research Gate, pp. 2-12.

Snyder, 1993. Donor bias towards small countries: An overlooked factor in the analysis of foreign aid and economic growth. Applied Economics, pp. 481-488.

TheGlobalEconomy, 2020. Zambia: Foreign Direct Investment, percent of GDP. [Online] Available at: https://www.theglobaleconomy.com/Zambia/Foreign_Direct_Investment/[Accessed 25 May 2020].

Tierney, 2017. China's Aid and Growth: Evidence from a New Global Development Finance Dataset. Aid Data Working Paper.

Wooldridge, 2009. Introductory Econometrics. 4th ed. s.1.:s.n. 